\title{
Periodic occurrence of epithelial viral necrosis outbreaks in Penaeus vannamei in Ecuador
}

\author{
R. Jimenez*, R. Barniol, L. de Barniol, M. Machuca \\ ACUATECNOS, PO Box 09-01-5738, Guayaquil, Ecuador
}

\begin{abstract}
Epizootics of an infectious cuticular epithelial necrosis virus (ICENV) occurred in cultured Penaeus vannamei in Ecuadorian shrimp farms from 1994 to 1996. There were few reports of outbreaks during 1997, but in the second half of 1998 epizootics were again reported. Histopathological examination revealed extensive tissue changes and necrosis as described for infections by what others have called Taura syndrome virus (TSV). Infiltration of haemocytes in the cuticular epithelium was also one of the characteristics in the subacute and acute forms of this disease. Electron microscopy of affected tissues demonstrated the presence of a single type of virus particle in the cytoplasm of diseased shrimps from these outbreaks and it corresponded to the published descriptions for TSV. The epizootics of ICENV were periodic in occurrence, and data indicated that they might be related to the oceanographic and climatic variations reported in the eastern Pacific from 1994 to 1998. Using 3 mo rolling averages, a statistically significant negative correlation was found between prevalence of ICENV and temperature but not temperature change. By contrast, there was a statistically significant positive correlation between prevalence of ICENV and salinity change but not salinity value. Although these data do not establish causal relationships, they suggest that laboratory tests should be conducted to determine whether low temperature and upward changes in salinity can increase shrimp susceptibility to infection and mortality by ICENV.
\end{abstract}

KEY WORDS: Infectious cuticular epithelial necrosis virus (ICENV) - Ultrastructure · Shrimp disease

\section{INTRODUCTION}

Increased awareness of the negative impact of diseases in shrimp farming has evolved with the impressive and rapid growth of penaeid shrimp aquaculture. An increase in reports of diseases with infectious and non-infectious aetiologies has also occurred (Lightner 1983, 1993). Probably the crash in Taiwanese shrimp farms was the first event that increased the awareness of disease and its role in penaeid shrimp aquaculture production (Lin 1989).

The 2 species of penaeid shrimp cultured in Ecuador are the Pacific white shrimp Penaeus vannamei (Boone) (also called Litopenaeus vannamei) and the blue shrimp P. stylirostris (Stimpson) (also called L. stylirostris). P. vannamei accounts for approximately $80 \%$ of the cultured shrimp production. During 1997 production of

*E-mail: mjimenez@impsat.net.ec pond-reared shrimp in Ecuador reached a record of 109000 t (Melendez 1998). During recent years different diseases affecting shrimp production have been reported in Ecuador (Lightner et al. 1992, Mohney et al. 1994, Jimenez et al. 1997, 1999). The most important disease until 1998 has been Taura syndrome (TS), which has affected cultured shrimp near the Taura river, as described by Jimenez (1992). However, in May 1999 using light microscopy white spot syndrome virus (WSSV) was diagnosed in shrimp ponds in Ecuador (R.J. pers. obs.). We disagree that TS is caused by Taura syndrome virus (TSV), but the issue will not be discussed in this paper as it has been covered in other publications (Jimenez et al. 1995, Brock et al. 1997, Intriago et al. 1997). The viral disease referred to as TSV by Brock et al. (1995) is found widely in Ecuador but we will call it infectious cuticular epithelial necrosis virus (ICENV) in this paper.

ICENV (= TSV) is currently characterised as a picornavirus (Bonami et al. 1997), and has been the focus of 
intense research (Lightner et al. 1994), most of which has centred on development of sensitive detection techniques, its effects on different sizes or other species of penaeids (Hasson et al. 1995, Lightner 1995, 1996, Lotz 1997, Overstreet et al. 1997, Mari et al. 1998, Nunan et al. 1998), reports of geographic extension (Hasson et al. 1999a), and progression of lesions under light microscopy (Hasson et al. 1999b).

Ecuadorian researchers have known viral diseases of the cuticular epithelium in cultured Penaeus vannamei since 1994 (Jimenez et al. 1995, Intriago et al. 1997). From 1994 to 1996 and again in late 1998, severe losses in shrimp production were related to such a disease in $P$. vannamei and referred to as infectious cuticular epithelial necrosis (ICEN) disease. In this manuscript, we describe histopathology and ultrastructure showing that the causative virus was similar or identical to TSV (Brock et al. 1995) and that fluctuations in outbreaks in Ecuador from 1994 until 1998 may have been related to major oceanographic and climatic changes.

\section{MATERIALS AND METHODS}

Sampling. Juvenile and adult penaeid shrimp samples were obtained from various commercial shrimp culture facilities in Ecuador from 1994 to 1998. Total sample size was based on 17783 individuals. Shrimp were collected and fixed in Davidson's AFA fixative and processed within $48 \mathrm{~h}$, as recommended by Bell \& Lightner (1988). Staining followed the methods outlined by Culling et al. (1985) for the H\&E and Giemsa, B\&B Gram (Luna 1968), and Steiner and Steiner methods (Steiner \& Steiner 1944). Histological sections of $5 \mu \mathrm{m}$ thickness were viewed using a Leitz Laborlux D microscope. Shrimp tissues for electron microscopy were preserved in $2.5 \%$ glutaraldehyde/ $\%$ paraformaldehyde in cacodylate buffer and postfixed in $1 \%$ osmium tetroxide. Samples were dehydrated and mounted in Spurr ${ }^{\mathrm{TM}}$ resin, and ultrathin sections were cut using a Reichert-Jung Ultracut E ultramicrotome. Sections were stained with lead citrate and uranyl acetate and examined with a JEOL/JEM 1200 EX-II transmission electron microscope (TEM).

In situ hybridization. A commercially available in situ hybridization probe for TSV (Diagxotics Inc.) was used according to the manufacturer's instructions. The protocols have been outlined by Lightner (1996) and others (Hasson et al. 1997, 1999a, Mari et al. 1998).

Statistical analysis. Monthly prevalence of disease during a 5 yr period was analysed using contingency tables combined with a chi-squared test, using the Minitab ${ }^{\mathrm{TM}}$ statistical program. Total number of positive and negative cases per year were added and later analysed using chi-squared. Correlation analysis was carried out using the Pearson product moment correlation test with SigmaStat computer software (Jandel Scientific). With this test, pairs of variables with positive correlation coefficients and $\mathrm{p}$ values below 0.05 tended to increase together. For the pairs with negative correlation coefficients and p values below 0.05 , one variable tended to decrease while the other increased. For pairs with $\mathrm{p}$ values greater than 0.05 , there is no significant relationship between the 2 variables. After correlation analysis, variables with significant correlation were graphed in scatterplots, and regression lines were drawn together with lines for prediction interval and confidence interval at either 95 or $99 \%$. For some comparisons, 3 mo rolling averages of mean monthly prevalence were tested against similar rolling averages of monthly mean temperature and salinity. Also tested was prevalence against mean monthly changes in temperature and salinity, both individually and as 3 mo rolling averages.

\section{RESULTS}

\section{Gross signs of disease}

From 1994 through 1996 and again in the second half of 1998, cultured Penaeus vannamei were severely affected by a highly acute and lethal disease called ICEN. Affected shrimp were within the size range of 1 to $10 \mathrm{~g}$. Size seemed to be more important than age in determining the onset of disease. When the shrimp reached approximately 2 to $4 \mathrm{~g}$, major mortality occurred. Survivors showed lethargy and chronic low mortality over the following 2 mo.

Affected shrimp showed signs of weakness that progressed to mortality when the shrimps stopped moving. Juvenile shrimp were most affected by subacute and acute ICEN disease. There was a noticeable discoloration of the cuticular epithelium to generally pale pink or pale brown. Individuals that survived the acute episode of ICEN sometimes showed melanized cuticular lesions, but this was not common.

\section{Histopathology, ultrastructure and in situ hybridization}

Histopathologically of acute ICENV disease was characterized by severe degenerative alterations and multifocal areas of necrosis in the cuticular epithelium and often, the subcuticular connective tissue, or the hypodermis of the foregut. Numerous basophilic spherical to oval pyknotic nuclei were scattered throughout the affected areas, and these were typically accompa- 



Fig. 1. Photomicrographs of histological sections of acute infectious cuticular epithelium necrosis (ICEN) in Penaeus vannamei. (a) Disorganization of the columnar cells of the cuticular epithelium, with large epithelial hyperplasia, nuclear pyknosis (arrow). Some nuclei appeared condensed (arrowhead). Numerous haemocytes (H) in the subcuticular tissue. H\&E. (b) Complete degeneration and necrosis of columnar cells of the cuticular epithelium. Nuclear pyknosis (arrow) derived to presence of numerous basophilic spherical to oval bodies (arrowheads) close to the cuticle (C). H\&E. Scale bars $=14 \mu \mathrm{m}$

nied by eosinophilic to basophilic material (Fig. 1). These characteristics corresponded to those described for TSV infections (Brock et al. 1995).

Ultrastructural examination of subacute ICENV lesions in juvenile and adult shrimp revealed electrondense chromatin in the process of condensation within the nucleus. The nuclear envelope was enlarged and disrupted, the rough endoplasmic reticulum (rER) was distended and the cytoplasm was darkened, indicating cellular degeneration and necrosis in contrast with normal cells (Fig. 2a). In addition, viral particles were observed individually or in irregular clusters in the cytoplasm (Fig. 2b,c).

In acute lesions, the nuclei of some epithelial cells were faded, the heterochromatin was partly uncondensed, and the cytoplasm was electron-light. Other cells showed pyknotic nuclei and very dark cytoplasm (Fig. 3a). These pyknotic nuclei displayed complete chromatin condensation into highly electron-dense, fine granular components. The cytoplasm also became electron-dense, and it also contained abnormal lucent cytoplasmic vacuoles with irregular clusters of virions, and viroplasm (Fig. 3b). The viral particles were approximately $30 \mathrm{~nm}$ in diameter; they did not form paracrystalline-like arrays (Fig. 3c). These characteristics correspond to the ultrastructure described for TSV (Brock et al. 1995).
In situ hybridization tests using a labeled probe for TSV gave a positive result with tissues of shrimp from ICEN disease outbreaks, giving further confirmation of the identity of the causative agent.

\section{Fluctuations in ICENV outbreaks}

The Gulf of Guayaquil is the largest estuary on the Pacific coast of South America. It is naturally divided into an outer estuary that commences near the western side of Puna Island. The inner estuary extends northeast from Puna Island for $74 \mathrm{~km}$ before narrowing into the channel of the Guayas river. Oceanic influences in the form of tides, however, extend up the river to and beyond the port city of Guayaquil.

The Gulf of Guayaquil is located in a tropical climate with marked wet and dry seasons. More than $95 \%$ of the annual precipitation falls during the wet season from December-January to May. By contrast, $5 \%$ or less of the yearly precipitation occurs during the dry season, which extends from June through November (Stevenson 1981).

Surface water temperature in the Gulf of Guayaquil exhibits a strong seasonal variation. During the dry season the surface temperature increases from $21.5^{\circ} \mathrm{C}$ at the mouth of the Gulf to $25^{\circ} \mathrm{C}$ in the inner estuary. In 



สึ



the interval between the dry season and the wet season the surface temperature generally becomes warmer, increasing to about $28^{\circ} \mathrm{C}$ in the inner estuary.

Changes in salinity are often more dramatic than other water-quality parameters normally measured. During the dry season the surface salinity decreases from $34 \mathrm{ppt}$ in the outer estuary to $30 \mathrm{ppt}$ in the inner estuary. In the wet season it is still 34 ppt in the outer estuary but can decrease sharply to only $20 \mathrm{ppt}$ in the inner region. Obviously, this decrease in surface salinity in the rainy season corresponds to an increase in river outflow (Stevenson 1981).

In summary, the dry season has high salinity and low temperatures, while the wet season has low salinity and high temperatures. El Niño events can change this 'normal' pattern by producing intervals of higher than normal temperatures and low salinities due to very heavy rainfall.

Shrimp farming is a year-round activity in Ecuador and the warm, wet season is generally regarded as better for shrimp rearing due mainly to the fact that wild postlarvae are more abundant and seem to be more resistant to desease than in the cool dry season. Survey data from 1994 to 1998 (Fig. 4) show that the prevalence of ICENV gave 3 major peaks, one from July 1994 to January 1995, one from June to November 1996 and one from May to December 1998 (i.e., mostly during warm, rainy weather). There was also high prevalence in January 1994, although this does not show up as a peak in Fig. 4. There was no period of major prevalence for most of 1995 and 1997, and up to the first half 1998. Thus, the peaks of high prevalence do not follow a yearly pattern except for the 2 periods of high prevalence in 1994. The mean peak-to-peak interval for the 3 clear peaks of high prevalence shown in Fig. 4 is $23.5 \mathrm{mo}$.

\section{Correspondence between oceanographic conditions and prevalence of ICENV}

Figs. 4 \& 5 summarize data on oceanographic changes and ICENV prevalence in the tropical Pacific and in the Gulf of Guayaquil, where most of the shrimp farms in Ecuador are located. The first epizootic 






of ICENV reported in 1994 coincided with cool conditions reported in the central Pacific and in the Gulf of Guayaquil, where temperatures ranged between 22 and $25^{\circ} \mathrm{C}$ from June to December 1994. It can be seen in Fig. 4 that the peak of ICENV prevalence occurred after a steady drop in temperature from approximately $29^{\circ} \mathrm{C}$ in March to approximately $23^{\circ} \mathrm{C}$ in July. Then, during most of 1995 warm conditions (CDB 1995-1996) occurred in the tropical Pacific and produced sea-surface temperatures (SST) up to $26^{\circ} \mathrm{C}$ in the inner estuary of the Gulf of Guayaquil, where the lack of rain during an unusually dry 'rainy season' contributed to an abnormally high salinity of up to 30 ppt. ICENV prevalence was low throughout the year.

Cool conditions again occurred in the tropical Pacific after January 1996. Coolerthan-normal SST were recorded in the Gulf of Guayaquil. From August to October 1996, cooler SST were reported in the outer estuary of the gulf $\left(21.5\right.$ and $\left.22.5^{\circ} \mathrm{C}\right)$ coinciding with a cool episode for the eastern equatorial Pacific (CDB 1995-1996). In the inner estuary of the gulf, SST ranged between 22 and $25^{\circ} \mathrm{C}$ and salinity ranged from 30 up to $40 \mathrm{ppt}$. In this area, where most of the shrimp farms are located, water temperature in shrimp ponds showed increased variability. On sunny days the water temperature ranged between $23^{\circ} \mathrm{C}$ in the morning and $33^{\circ} \mathrm{C}$ in the evening, with salinity rising up to 35 ppt. In shallower nursery ponds, even higher variability could be expected and could cause additional stress. These changes coincided with ICENV outbreaks showing cumulative mortalities of 80 to $90 \%$. Dead and dying shrimp appeared in seines or cast nets used for routine pond sampling. Again, as in 1994, the rise in ICENV prevalence followed a drop in temperature from approximately $27^{\circ} \mathrm{C}$ in February to approximately $22^{\circ} \mathrm{C}$ in June.

The El Niño-Southern Oscillation (ENSO) phenomenon refers to a coupled oceanic and atmospheric interaction known to be a central factor in short-term climate variability throughout the globe, particularly in the tropics. During the strong El Niño event development in most of 1997 and during the first half of 1998, warm conditions in the tropical Pacific eastward to the 


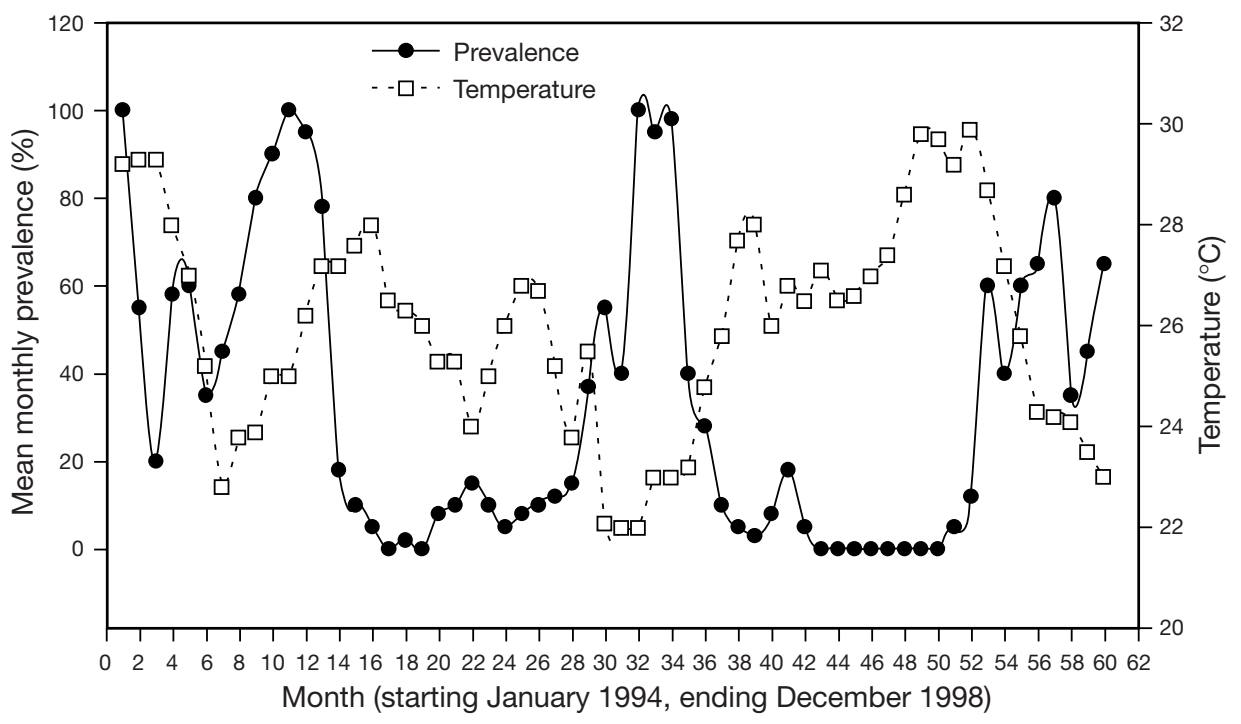

Fig. 4. Mean monthly prevalence of ICENV and temperature over 60 mo from January 1994 to December 1998. Prevalence of ICEN disease had major peaks in 1994, 1996 and second half of 1998. There was no period of major prevalence for most of 1995 and 1997 to the first half of 1998

South American coast led to temperatures in the Gulf of Guayaquil between 27.0 and $30.0^{\circ} \mathrm{C}$. The higher temperatures coincided with low salinities between 15 and 20 ppt in the inner estuary, and lower salinities were recorded especially during the heavy rains of 1998 at the second peak of El Niño (Fig. 5), when there was a dramatic decrease in salinity to lower than 5 ppt (Cucalon 1997). During these months in 1997 and 1998, ICENV outbreaks were not reported and shrimp survival was above $50 \%$ using direct stocking. This was true for ponds from different farms stocked with either wild or hatchery-reared postlarvae, the hatchery postlarvae being derived from either wild or maturation broodstock. However, when temperatures in the tropical Pacific and the Gulf of Guayaquil decreased to lower than $24^{\circ} \mathrm{C}$ around September 1998, ICENV outbreaks were again reported from shrimp farms in the
Gulf of Guayaquil. In contrast to 1994 and 1996, the prevalence of ICENV began to increase sharply before the fall in temperature and not afterwards. On the other hand, it did increase in prevalence after a sharp decrease in salinity from 20 ppt in October to 0 ppt in February.

Because of the periodic occurrence of ICENV outbreaks and the possible correspondence with oceanographic data, a series of tests were carried out to determine whether there was any statistical correlation between prevalence of ICENV and temperature and/ or salinity. As expected (Fig. 6), there was a significant negative correlation between temperature and salinity because of the warm rainy season and cool dry season.

There was a significant negative correlation between prevalence and temperature (i.e., higher prevalence corresponded to lower temperatures). The best



Fig. 5. Mean monthly prevalence of ICENV and salinity over 60 mo from January 1994 to December 1998. Prevalence of ICEN disease had major peaks in 1994, 1996 and second half of 1998. There was no period of major prevalence for most of 1995 and 1997 to the first half of 1998 




Fig. 6. Relationship between mean monthly temperature and mean monthly salinity. A linear regression line together with predictions and confidence intervals at $99 \%$ (thin solid and dotted lines, respectively) are shown. The Pearson product moment correlation coefficient is -0.54 with $\mathrm{p}=0.00001$ $\left(r^{2}=0.29\right)$, indicating a statistically significant negative correlation

correlation coefficient was obtained when using 3 mo rolling averages for the comparison (Fig. 7). By contrast, there was no significant correlation between prevalence and temperature change or rate of temperature change over the previous month or previous few months $(\mathrm{p}>0.05)$.

With salinity, there was a significant positive correlation between 3 mo rolling averages of mean preva-



Fig. 7. Relationship between 3 mo rolling averages of prevalence and temperature. A linear regression line together with prediction and confidence intervals at $99 \%$ (thin solid and dotted lines, respectively) are shown. The Pearson product moment correlation coefficient is -0.51 with $\mathrm{p}=0.00004\left(\mathrm{r}^{2}=\right.$ 0.26 ), indicating a statistically significant negative correlation

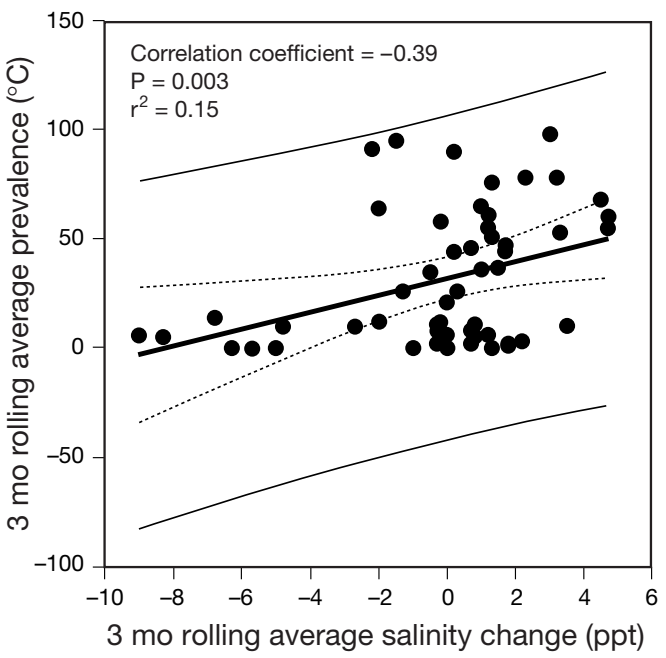

Fig. 8. Relationship between 3 mo rolling averages of prevalence and difference in mean salinity for the current month and preceding month. A linear regression line together with prediction and confidence intervals at $99 \%$ (thin solid and dotted lines, respectively) are shown. The Pearson product moment correlation coefficient was 0.39 with $\mathrm{p}=0.003\left(\mathrm{r}^{2}=\right.$ $0.15)$, indicating a statistically significant positive correlation

lence and differences in mean salinity between months (Fig. 8) (i.e., increases in salinity were correlated with increases in prevalence). In contrast, there was no significant correlation found between mean prevalence and mean salinity value. The correlation coefficient shown in Fig. 8 is not high, and the relationship may have resulted simply because of the correlation between temperature and salinity already shown in Fig. 6.

\section{DISCUSSION}

The data presented here show a statistically significant negative correlation between ICENV prevalence and temperature. In 2 cases, major increases in prevalence of ICENV were preceded by periods of large temperature drops during transitions from warm to cool weather. This suggests that cool weather may be a precipitating factor for ICENV outbreaks. However, the data for 1998 are not entirely consistent with this in that there was a sharp rise in ICENV prevalence before the temperature began to fall. This does not entirely discount cool temperatures as a precipitating factor, but may simply indicate that other factors can also be important. For example, management decisions are important in controlling the incidence of ICENV. However, these are unlikely to have been the cause of the rapid increase in ICENV prevalence in 1998, since the same management practices were used then as in 1997, when the prevalence of ICENV was low and a record year of production was achieved (Melendez 1998). 
Statistical analysis of the relationship between ICENV prevalence and change in salinity revealed a significant positive correlation, although the correlation coefficient was weaker than that for prevalence versus temperature. However, it is important that it was the change in salinity and not the salinity value that gave a significant correlation. It is not clear why prevalence is correlated to temperature value but not rate of change and to salinity rate of change but not value. If these parameters are causally linked to ICENV outbreaks, it is possible that this difference indicates distinctive mechanisms of action for the 2 environmental factors. From the data in hand, the correlation of prevalence to temperature and salinity change cannot be considered causal. However, it suggests that laboratory tests on the effect of temperature and salinity change on ICENV virulence, both individually or in concert, would be appropriate.

\section{LITERATURE CITED}

Bell TA, Lightner DV (1988) A handbook of normal penaeid shrimp histology. The World Aquaculture Society, Baton Rouge, LA

Bonami JR, Hasson KW, Mari J, Poulos BT, Lightner DV (1997) Taura syndrome of marine penaeid shrimp: characterization of the viral agent. J Gen Virol 78:313-319

Brock JA, Gose R, Lightner DV, Hasson KW (1995) An overview of Taura syndrome, an important disease of farmed Penaeus vannamei. In: Browdy CL, Hopkins JS (eds) Swimming through troubled water. Proceedings of the special session on shrimp farming, World Aquaculture Society, Baton Rouge, LA, p 84-94

Brock JA, Gose R, Lightner DV, Hasson K (1997) Recent developements and an overview of Taura Syndrome of farmed shrimp in the Americas. In: Flegel TW, MacRae IH (eds) Diseases in Asian aquaculture III. Fish Health Section, Asian Fisheries Society, Manila, p 275-283

CDB (Climate Diagnostic Bulletin) (1995-1996) Climate Prediction Center. US Department of Commerce, National Oceanic and Atmospheric Administration, Washington, DC

Cucalon E (1997) Oceanographic variability in Campo Amistad, Gulf of Guayaquil, Ecuador. Energy Development Corporation (EDC), Guayaquil, p 1-73

Culling CFA, Allison RT, Bar WT (1985) Cellular pathology techniques, 4 th edn. Butterworths, London

Hasson KW, Lightner DV, Poulos BT, Redman RM, White BL, Brock JA, Bonami JR (1995) Taura syndrome in Penaeus vannamei: demonstration of a viral etiology. Dis Aquat Org 23:115-126

Hasson KW, Hasson J, Aubert H, Redman RM, Lightner DV (1997) A new RNA-friendly fixative for the preservation of penaeid shrimp samples for virological detection using cDNA genomic probes. J Virol Methods 66:227-336

Hasson KW, Lightner DV, Mari J, Bonami JR, Poulos BT, Mohney LL, Redman RM, Brock JA (1999a) The geographical distribution of Taura Syndrome Virus in the Americas: determination by histology and in situ hybridization using TSV-specific cDNA probes. Aquaculture 171: $13-26$

Hasson KW, Lightner DV, Mohney LL, Redman RM, Poulos BT, White BM (1999b) Taura syndrome virus (TSV) lesion development and the disease cycle in the Pacific white shrimp Penaeus vannamei. Dis Aqua Org 36:81-93

Intriago P, Jimenez R, Machuca M, Barniol R, Krauss E, Salvador X (1997). Experiments on toxicosis as the cause of Taura syndrome in Penaeus vannamei in Ecuador. In: Flegel TW, MacRae IH (eds) Diseases in Asian aquaculture III. Fish Health Section, Asian Fisheries Society, Manila, p 365-379

Jimenez R (1992) Sindrome de Taura (Resumen). Rev Acuacult Ecuador 1:1-16

Jimenez R, Barniol R, Machuca M (1995) Taura Syndrome: epizootiology and histopathology of a mortality toxicity syndrome of penaeid shrimp in Ecuador. In: Abstracts of world aquaculture 95. World Aquaculture Society, Baton Rouge, LA, p 147

Jimenez R, Barniol R, Machuca M (1997) An epizootic of an intracellular bacterium in cultured penaeid shrimp (Crustacea: Decapoda) in the Gulf of Guayaquil. In: Flegel TW, MacRae IH (eds) Diseases in Asian aquaculture III. Fish Health Section, Asian Fisheries Society, Manila, p 305-311

Jimenez R, Barniol R, de Barniol L, Machuca M (1999) Infection of IHHN virus in two species of cultured penaeoid shrimp, Litopenaeus vannamei (Boone) and Litopenaeus stylirostris (Stimpson), in Ecuador during El Niño 1997-1998. Aquacult Res 30:695-705

Lightner DV (1983) Diseases of cultured penaeid shrimp. In: McVey JP (eds) Handbook of mariculture crustacean aquaculture, Vol 1. CRC Press, Boca Raton, FL, p 289-320

Lightner DV (1993) Diseases of cultured penaeid shrimp. In: McVey JP (ed) Handbook of mariculture: crustacean aquaculture, Vol 1, 2nd edn. CRC Press, Boca Raton, FL, p 393-486

Lightner DV (1995) Taura Syndrome: an economically important viral disease impacting the shrimp farming industries of the Americas including the United States. In: Proceedings of the 99th Annual Meeting USAHA, Reno, NV. P. Campbell \& Associates, Richmond, VA, p 36-52

Lightner DV (1996) A handbook of pathology and diagnostic procedures for diseases of penaeid shrimp. World Aquaculture Society, Baton Rouge, LA

Lightner DV, Bell TA, Redman RM, Mohney LL, Natividad JM, Rukyano A, Poernomo A (1992) A review of some major diseases of economic significance in penaeid prawns/shrimps of the Americas and Indopacific. In: Shariff M, Subashinghe RR, Arthur JR (eds) Diseases in Asian aquaculture I. Fish Health Section, Asian Fisheries Society, Manila, p 57-80

Lightner DV, Jones LS, Ware GW (1994) Proceedings of the Taura Syndrome Workshop: executive summary; submitted reports, and transcribed notes. January 21-22, 1994. Univ of Arizona, Tucson

Lin CV (1989) Prawn culture in Taiwan-what went wrong? World Aquacult 20:19-20

Lotz JM (1997) Effect of host size on virulence of Taura Virus to the marine shrimp Penaeus vannamei (Crustacea: Penaeidae). Dis Aquat Org 30:45-51

Luna LG (1968) Manual of histological staining methods of the Armed Forces Institute of Pathology, 3rd edn. McGraw Hill, New York

Mari J, Bonami JR, Lightner DV (1998) Taura syndrome of penaeid shrimp: cloning of viral genome fragments and development of specific gene probes. Dis Aquat Org 33: $11-17$

Melendez ML (1998) Ecuador: exportaciones de camaron 1997, año record. Rev Acuacult Ecuador 23:22-27

Mohney LL, Lightner DV, Bell TA (1994) An epizootic of vibriosis in Ecuadorian pond-reared Penaeus vannamei, 
Boone (Crustacea: Decapoda). J World Aquacult Soc 25: 116-125

Nunan LM, Poulos BT, Lightner DV (1998) Reverse transcription polymerase chain reaction (RT-PCR) used for the detection of Taura Syndrome Virus (TSV) in experimentally infected shrimp. Dis Aquat Org 34:87-91

Overstreet RM, Lightner DV, Hasson KW, Mcllwain S, Lotz JM (1997) Susceptibility to Taura Syndrome Virus of some penaeid shrimp species native to the Gulf of Mexico

Editorial responsibility: Timothy Flegel,

Bangkok, Thailand and the Southeastern United States. J Invertebr Pathol 69: $165-176$

Steiner G, Steiner G (1944) New simple silver stain for demonstration of bacteria, spirochetes and fungi in sections from paraffin embedded tissue blocks. J Lab Clin Med 29: 868-871

Stevenson MR (1981) Seasonal variations in the Gulf of Guayaquil, a tropical estuary. Bull Inst Nacional Pesca Ecuador 4(1):1-133

Submitted: March 19, 1999; Accepted: March 31, 2000

Proofs received from author(s): July 17, 2000 